ОКСАНА ЦЮНЯК, кандидат педагогічних наук,

дочент, кафедра педагогіки початкової освіти, ДВНЗ "Прикарпатський національний університет імені Василя Стефаника", Україна orcid.org/0000-0002-4573-1865 tsiuniak33@gmail.com

\title{
ПРОФЕСІЙНА ПІДГОТОВКА МАЙБУТНІХ МАГІСТРІВ ПОЧАТКОВОЇ ОСВІТИ ДО ІННОВАЦІЙНОЇ ДІЯЛЬНОСТІ ЯК НАУКОВА ПРОБЛЕМА
}

\author{
OKSANA TSIUNIAK, Candidate of Pedagogical Sciences, \\ Associate Professor of the Chair of Pedagogy of Primary \\ Vasyl Stefanyk Precarpathian NationaUniversity, Ukraine

\section{PROFESSIONAL TRAINING OF FUTURE MASTERS OF ELEMENTARY EDUCATION TO INNOVATIVE ACTIVITY AS A SCIENTIFIC CHALLENGE}

\begin{abstract}
Стаття присвячена проблемі професійної підготовки майбутніх педагогів у закладах вищої освіти. Зокрема, розкрито сутність поняття професійна підготовка майбутніх магістрів початкової освіти до інноваційної діяльності. На основі аналізу різноманітних трактувань сутності професійної підготовки запропоновано власне формулювання означеної дефініції. Автор зазначає, що "професійна підготовка майбутніх магістрів початкової освіти до інноваційної діяльності" ? це система організаційно-педагогічних умов, відповідного освітнього середовища закладу вищої освіти та наявності навчально-методичного забезпечення, спрямованих на формування професійної готовності магістрантів до інноваційної діяльності.
\end{abstract}

Ключові слова: професійна підготовка, майбутні магістри початкової освіти, інноваційна діяльність, професійна готовність до інноваційної діяльності, заклад вищої освіти.

Summary. The article is devoted to the issue of future teachers' professional training in higher education institutions. In particular, the essence of the concept of "professional

(c) О. Цюняк preparation of future masters of elementary education to innovative activity" is revealed. Based on the analysis of various interpretations of the essence of professional training, our own formulation of the definition is proposed. The author notes that "professional preparation of future masters of elementary education to innovative activity" is a system of organizational and pedagogical conditions, appropriate educational environment of higher education institutions and availability of educational and methodological support focused on forming the magistrands' professional readiness to innovative activity.

Key words: vocational training, future masters of elementary education, innovative activity,

Мета: 3'ясувати сутність поняття професійна підготовка майбутніх магістрів початкової освіти до інноваційної діяльності у вимірі сучасного наукового знання.

Постановка проблеми в загальному вигляді. Реалії сучасного світу, трансформаційні процеси в системі освіти, соціальне замовлення ринку праці спонукають до перегляду окремих усталених поглядів на цілі та завдання вищої освіти загалом та професійної підготовки фахівців зокрема. Відтак перед сучасною системою вищої освіти України стоїть ціла низка стратегічних завдань, що потребують нагального вирішення, а саме: визначення стратегічних пріоритетів вищої освіти; контроль якості освіти; зв'язок з виробництвом; активна інтеграція науки та освіти; економічна підтримка напрямів наукової та освітньої діяльності; налагодження механізму раціонального фінансування, ефективного впровадження новітніх освітніх технологій тощо.

Вважаємо за необхідне зазначити, що саме з позицій сьогодення закладам вищої освіти значну увагу слід приділяти підготовці компетентного, відповідального фахівця, конкурентоздатного на ринку праці, професійно готового до ефективної роботи за обраною спеціальністю на рівні світових стандартів, здатного до соціальної і професійної мобільності, постійного фахового зростання та самовдосконалення. Так, нам імпонують міркування В. Кременя стосовно того, що процеси глобалізації, змінності, конкуренції, що з кожним роком владніше заявляють про себе у світі, зобов'язують нарощувати дослідницькі зусилля 3 осмислення ролі освіти у формуванні людини, адекватної інноваційному типу суспільного про- 
гресу - інноваційної людини. Цілком погоджуємося 3 думкою ученого про те, що досягнення конкурентоспроможної якості національної освіти в контексті цивілізаційних змін нині стає пріоритетом модернізації освіти України (Кремень, 1999, с. 1017).

Резюмуючи зазначене, доходимо висновку, що сьогодення вимагає ефективної системи професійної підготовки майбутніх фахівців, у нашому випадку майбутніх магістрів початкової освіти, котрі будуть готовими до інноваційної діяльності. Тому виникає необхідність з'ясувати сутність професійної підготовки у вимірі сучасного наукового знання.

Аналіз досліджень і публікацій. Наукові розвідки доводять, що теорія і практика професійної підготовки майбутніх фахівців до інноваційної діяльності залишається недостатньо розробленою в умовах нової педагогічної реальності. Питаннями професійної підготовки майбутніх фахівців займалися як зарубіжні (А. Маслоу, К. Роджерс), так і вітчизняні (Г. Абрамова, О. Бондаренко, М. Боришевський, Л. Бурлачук, Н. Зубалій, Н. Коломінський, О. Макаренко, С. Максименко, В. Моргун, В. Татенко, Т. Титаренко, М. Савчин, В. Панок, Т. Яценко та ін.) дослідники. Проблемою професійно-педагогічної підготовки вчителя та стратегій формування його професіоналізму присвячено наукові праці А. Алексюка, Г. Васяновича, О. Дубасенюк, I. Зязюна, Л. Хомич та ін., а психології професійної діяльності та професійного розвитку педагога - Г. Балла, Н. Побірченко, В. Рибалки, В. Семиченко та інших.

Питання професійної підготовки фахівців освітнього рівня "магістр" спеціальності 013 Початкова освіта залишається пріоритетною у педагогічній науці і практиці. Педагогічне осмислення професійної підготовки майбутніх учителів здійснили у своїх дослідженнях О. Абдуліна, В. Берека, М, Бубнова, І. Зязюн, Н. Ігнатенко, Л. Йовенко, В. Кузь, О. Мисечко, О. Павлик, Л. Поліщук, Л. Хомич, Л. Хоружа та інші.
Виклад основного матеріалу дослідження. Убачаємо необхідність у тому, щоб визначитись 3 понятійним апаратом у межах означеної проблеми та для початку схарактеризуємо терміни професійна підготовка та професійна готовність у вимірі сучасної науки. Для уточнення іхнього змісту ми застосовуємо метод контекстного аналізу як дослідницького інструментарію, що передбачає поетапну процедуру вивчення визначеної категорії (поняття, педагогічного явища) у системі психолого-педагогічних наук (Дубасенюк, 2010 , 200-221).

Аналіз змісту поняття професійна підготовка доцільно розпочати зі з'ясування сутності базового терміна підготовка. У науково-педагогічному вимірі категорію підготовка прийнято трактувати як запас знань, умінь i навичок, досвід особистості, набуті у процесі навчання і практичної діяльності (Великий тлумачний словник сучасної української мови, 2002, с. 952).

У нашому дослідженні ми оперуємо поняттям готовність, яке дефінюється як наявність здібностей (Б. Ананьєв, С. Рубінштейн), якостей особистості (К. Платонов), психологічний стан, суттєва ознака установки (Д. Унадзе), психологічна умова успішності виконання діяльності (I. Ладанов), цілісне явище, скріплене переконаннями, морально-вольовими якостями особистості, способами поведінки, знаннями про професію та практичними вміннями і навичками (Р. Романенко; В. Сєріков).

У Тлумачному словнику української мови знаходимо визначення готовності як бажання зробити що-небудь (Тлумачний словник украйнської мови, 2012). У Словнику психологопедагогічних понять і термінів готовність трактується як стан особистості, який дозволяє їй успішно ввійти у професійне середовище, швидко розвиватися у професійному напрямі (Словник психолого-педагогічних понять, 2012).

Лаконічний аналіз сутності понять підготовка та готовність дозволяє здійснити їх диференціацію, визначаючи термін про- фесійна підготовка як процес навчання (формування професійної готовності), а поняття професійна готовність - як результат професійної підготовки, психічний стан та якісні особистісні характеристики, що регулюють цей стан.

В Українському педагогічному словнику професійну підготовку висвітлено як "сукупність спеціальних знань, навичок та вмінь, якостей, трудового досвіду і норм поведінки, що забезпечують можливість успішної роботи з певної профресії" (Гончаренко, 1997).

Дослідник О. Павлик пояснює дефініцію професійна підготовка як складну психолого-педагогічну систему зі специфічним змістом, наявністю структурних елементів, формами зв'язків, особливостями навчального процесу, специфічного для певного фаху знаннями, уміннями і навичками (Павлик, 2004, с. 20); науковець Г. Троцко тлумачить професійну підготовку як систему, що характеризується взаємозв'язком та взаємодією структурних і функціональних компонентів, сукупність яких визначає особливість, що забезпечує формування особистості студента відповідно до поставленої мети - вийти на якісно новий рівень готовності студентів до професійної діяльності (Троико, 1997, с. 54); дослідник Ю. Забіяко розглядає професійну підготовку як цілісну систему мір, методів і прийомів, що будується 3 урахуванням особистісних якостей фахівця, має чітку визначену структуру і специфіку та забезпечує загальну і спеціальну підготовку (Забіяко, 2013, с. 1619).

Цікавим є твердження дослідниці О. Андрусь (2011) про те, що професійна підготовка - це "організаційно-методичний процес формування у студентів їх професійної компетентності, активної життєвої позиції, внутрішньої культури, здатності до продуктивного спілкування 3 навколишнім світом для професійно особистісної та соціальної реалізації, навчання та самоосвіти впродовж життя" (Андрусь, 2011, 283-294).

Принагідно зазначимо, що 
вчена Н. Івасів (2017) стверджує, що "у сучасній психологопедагогічній літературі існує декілька підходів до визначення сутності професійної підготовки. Психологи розглядають їі як засіб приросту індивідуального потенціалу особистості, розвитку резервних сил, пізнавальної і творчої активності на основі оволодіння загальнонауковими та професійно значущими знаннями, уміннями і навичками. Представники педагогічної науки вбачають сутність такої підготовки в набутті людиною професійної освіти, що є результатом засвоєння інтелектуальних знань, умінь та формування необхідних особистісних професійних якостей" (Івасів, 2017, с. 21-25).

Цінними для нашого дослідження є міркування науковців Е. Азимова і А. Щукіна, котрі у Новому словнику методичних термінів і понять дають визначення професійної підготовки як системи організаційних і педагогічних заходів, що забезпечує формування в особистості професійної спрямованості знань, навичок, умінь та професійної готовності до певної діяльності (Лянной, 2017, с. 663). Як бачимо, термін професійна підготовка характеризується поняттям професійна готовність.

Особливу увагу привертають міркування вчених В. Жигірь та О. Чернєга, котрі зазначають, що основними компонентами професійної підготовки майбутніх магістрів є: "... знання предметної галузі, володіння іноземною мовою, комп'ютерна грамотність. Навчання в магістратурі спрямоване на підготовку випускника, здатного кваліфіковано вирішувати наукові завдання в конкретному професійному напрямі і до педагогічної діяльності за цим напрямом. Магістерська підготовка передбачає проведення наукових досліджень, результати яких можуть бути опубліковані або висвітлені на конференціях і семінарах" (Жигірь, Чернєга, 2012, c. 185).

Педагогічна підготовка магістрів, як стверджує С. Вітвицька, - це поєднання загального, особливого й індивідуального. Сутність загального полягає у відображенні здобуття вищої освіти і є складовою означеної системи; особливого - у специфіці, зумовленій характеристиками майбутньої професійної інноваційної діяльності, необхідністю поєднання фахової, педагогічної та науково-дослідницької діяльності; індивідуального - у залежності підготовки від індивідуальних особливостей, рівня знань, інтересів, нахилів (Вітвицька, 2004). Дослідження процесу педагогічної підготовки магістрантів, на думку С. Вітвицької, передбачає вивчення не тільки загальнопедагогічних i дидактичних факторів, але і гносеологічних, ідеологічних, психологічних, соціально-психологічних, соціологічних, культурологічних та інших. Педагогічну підготовку студентів магістратури дослідниця подає в аспекті системного розвитку, зосереджуючи увагу не тільки на те, як ця система функціонує, але й на те, як вона взаємодіє 3 іншими системами в умовах ступеневої освіти, які тенденції та перспективи іiі розвитку й удосконалення (Вітвицька, 2005, с. 8-12). Узагальнення різних підходів до розуміння сутності поняття професійна підготовка, дозволило сформулювати власну дефініцію. У контексті означеної проблеми професійну підготовку майбутніх магістрів початкової освіти до інноваційної діяльності розуміємо як систему організаційно-педагогічних умов, відповідного освітнього середовища 3 ВО та наявності навчально-методичного забезпечення, спрямованих на формування професійної готовності до інноваційної діяльності.

Вважаємо, що специфічною особливістю професійної підготовки в закладах вищої освіти, особливо в умовах магістратури, є те, що засвоєння змісту навчання і розвиток особистості здобувача вищої освіти має відбуватися не у процесі його інформування, а власної активної діяльності. Майбутній магістр повинен отримати таку підготовку, яка полягала б у засвоєнні комплексу необхідних загальнотеоретичних знань, професійних умінь і навичок для успішного виконання професійних функцій, розвитку високого рівня інтелекту, регламентованого загальним стандартом вищої освіти, за яким у магістрантів формується цілісне уявлення про майбутню професійну діяльність.

Отже, виникає необхідність розглянути сутність поняття професійна готовність.

Погоджуємося 3 твердженням С. Гаркуші (2013) про те, що "результатом професійної підготовки є готовність" (Гаркуша, 2013, с. 198-201).

Згідно $з$ логікою нашого дослідження вважаємо за необхідне здійснити осмислення поняття інноваційна діяльність. Наукові розвідки доводять, що одним 3 різновидів педагогічної діяльності є інноваційна педагогічна діяльність, яка, як зазначають науковці, сприяє оновленню педагогічного процесу та характеризується високою педагогічною творчістю. У Законі України "Про інноваційну діяльність" ідеться про спрямованість інноваційної діяльності на творчу реалізацію наукових досліджень та розробок, що сприяє утворенню й випуску на ринок нових конкурентоздатних товарів і послуг (Закон України "Про інновачійну діяльність" від 4 липня 2002 p. № 40-IV).

Науковець О. Гончарова зазначає, що це "системна діяльність, спрямована на реалізацію нововведень на основі використання та впровадження нових наукових ідей, знань, підходів або трансформації відомих результатів наукових досліджень та практичних розробок у новий або вдосконалений продукт" (Гончарова, 2014, с. 8992).

У цьому аспекті варто взяти до уваги, що інноваційна діяльність майбутніх магістрів початкової освіти - вимога сучасної освіти, важлива складова професійного зростання майбутнього фахівця. Важливим у нашому дослідженні $\epsilon$ те, що майбутні магістри початкової освіти, на відміну від магістрів інших спеціальностей, отримують знання з багатьох дисциплін, оскільки вони викладатимуть різні навчальні предмети - математику, природознавство, письмо, читання, малювання, співи, трудове навчання, організовуватимуть предметні ранки, виховні 
заходи тощо. Крім того, майбутній магістр початкової освіти $\epsilon$ викладачем педагогіки та методики початкової освіти (педагогічних дисциплін). $\mathrm{He}$ обхідність оновлення системи професійної підготовки майбутніх магістрів початкової освіти обумовлена не тільки формуванням високого рівня їхньої інноваційної компетентності, а й формуванням професійної готовності до інноваційної діяльності, уведення та реалізації у власній діяльності освітніх інновацій. Адже сучасний педагог $є$ водночас розробником навчальних програм, дослідником педагогічного процесу, організатором освітньої діяльності, громадським діячем, агентом змін, менеджером, модератором, тренером, тьютором, коучем, фасилітатором.

Отже, здійснивши грунтовний аналіз наукових розвідок і дисертаційних досліджень 3 означеної проблеми, пропонуємо авторське визначення. Вважаємо, що професійна готовність майбутніх магістрів початкової освіти до інноваційної діяльності - це результат професійної підготовки, інтегративне особистісне утворення, що характеризується поєднанням когнітивного (знання про зміст професії та інноваційної діяльності), мотиваційного (мотиви до інноваційної діяльності та інтереси), рефлексивного (уміння аналізувати результати інноваційної діяльності) та праксеологічного (актуалізація інноваційної компетентності) компонентів, що дозволяють виконувати професійні завдання інноваційного характеру.

Висновки та перспективи подальших досліджень. Таким чином, аналіз наукової думки щодо досліджуваної проблеми засвідчив, що обрана тема є актуальною та доцільною для вивчення. Незважаючи на те, що різні аспекти означеного питання неодноразово порушувались значною кількістю науковців, теоретичні і методичні засади професійної підготовки майбутніх магістрів початкової освіти до інноваційної діяльності залишаються невизначеними.

Теоретичне обгрунтування базових понять дослідження дає підстави для розгортання подальшої роботи щодо розроблення системи професійної підготовки майбутніх магістрів початкової освіти до інноваційної діяльності.

\section{СПИСОК ЛІТЕРАТУРИ}

Андрусь, О. (2011). Сучасні аспекти професійної підготовки студентів у технічних університетах. Проблеми підготовки сучасного вчителя, 4 (2), 283-294.

Великий тлумачний словник сучасної української мови: 170 000 слів. (2002). Київ; Ірпінь : Перун.

Вітвицька, С. С. (2004). Теоретичні засади підготовки магістрів в умовах ступеневої педагогічної освіти. Взято $3 \mathrm{http}: /$ /eprints.zu.edu.ua/ 351/1/ 04vssspo.pdf).

Вітвицька, С. С. (2005). Методологічні основи ступеневої педагогічної освіти. Вісник Житомирського державного університету імені Івана Франка. Взято 3 http://eprints.zu.edu.ua/165/1/ cd1.pdf).

Галицька, М. М. (2007). Формування у студентів вищих навчальних закладів сфери туризму готовності до іншомовного спілкування. (Атореф. дис. канд. пед. наук). Інститут педагогіки i психології професійної освіти АПН України, Київ.

Гаркуша, С. (2013). Поняття та компоненти професійної готовності майбутніх учителів до педагогічної діяльності. Вісник Чернігівського національного педагогічного університету, 110 , 198-201.

Гончарова, О. А. (2014). Структура інноваційної діяльності майбутнього вчителя іноземної мови. Молодий вчений, 1 (04), 89-92.

Дубасенюк, О. А. (2010). Використання методу контент-аналізу для дослідження категоріально-поняттєвого апарату у системі педагогічного знання. Вінниця : вид-во АМСКП, 200-221.

Жигірь, В. І., Чернєга, О. А. (2012). Професійна педагогіка. Київ : Кондор.

Забіяко, Ю. (2013). Професійна підготовка фахівців фізичної культури та спорту. Фізичне виховання, спорт і культура здоро- в'я у сучасному суспільстві, 2.

Івасів, Н. С. (2017). Професійна іншомовна підготовка майбутніх фахівців з туризмознавства як педагогічна проблема. Science and Education a New Dimension, 54 (126), 21-25.

Кремень, В. Г. (1999). Національна освіта як соціокультурне явище. Учитель, 11-12, 10-17.

Лянной, Ю. О. (2017). Теоретичні і методичні засади професійної підготовки майбутніх магістрів з фізичної реабілітації у вищих навчальних закладах. (Дисертація ... доктора педагогічних наук). Національний педагогічний університет імені М. П. Драгоманова, Київ.

Павлик, О. Б. (2004). Професійно-педагогічна підготовка майбутніх перекладачів до використання офіційно-ділового мовлення. (Автореф. дис. ... канд. пед. наук). Хмельницький.

Словник психолого-педагогічних понять. (2012).

Тлумачний словник української мови. (2012). Взято $3 \mathrm{http}: / /$ sum.in.ua/f.

Троцко, Г. В. (1997). Теоретичні та методичні основи підготовки студентів до виховної діяльності у вищих педагогічних навчальних закладах. (Автореф. дис. ... доктора пед. наук). Київ : Інститут ПППО.

Цюняк, О. (2019). Філософське осмислення поняття "інноваційна діяльність". Молодий вчений, 5, 175-178.

\section{REFERENCES}

Andrus, O. (2011). Suchasni aspekty profesiinoi pidhotovky studentiv u tekhnichnykh universytetakh. (Modern aspects of professional training of students in technical universities). Problemy pidhotovky suchasnoho vchytelia, 4 (2), 283-294.

Velykyi tlumachnyi slovnyk suchasnoi ukrainskoi movy: 170 000 sliv (2002). Kyiv; Irpin : Perun.

Vitvytska, S. S. (2004). Teoretychni zasady pidhotovky mahistriv $\mathrm{v}$ umovakh stupenevoi pedahohichnoi osvity (Theoretical bases of preparation of masters in the conditions of the stage pedagogical education). Retrieved from http://eprints.zu.edu.ua/ 351/ 1/ 04vssspo.pdf. 
Vitvytska, S. S. (2005). Metodolohichni osnovy stupenevoi pedahohichnoi osvity. (Methodological foundations of step-by-step teacher education). Visnyk Zhytomyrskoho derzhavnoho universytetu imeni Ivana Franka. Retrieved from http:/ /eprints.zu.edu.ua/165/1/cd1.pdf.

Halytska, M. M. (2007). Formuvannia u studentiv vyshchykh navchalnykh zakladiv sfery turyzmu hotovnosti do inshomovnoho spilkuvannia, (Formation of tourism readiness for foreign language communication among university students). (Atoref. dys. kand. ped. nauk). Instytut pedahohiky i psykholohii profesiinoi osvity APN Ukrainy, Kyiv.

Harkusha, S. (2013). Poniattia ta komponenty profesiinoi hotovnosti maibutnikh uchyteliv do pedahohichnoi diialnosti. (Concepts and components of future teachers' professional readiness for pedagogical activity). Visnyk Chernihivskoho natsionalnoho pedahohichnoho universytetu, 110 , 198-201.

Honcharova, O. A. (2014). Struktura innovatsiinoi diialnosti maibutnoho vchytelia inozemnoi movy. Molodyi vchenyi, 1 (04), 89-92.

Dubaseniuk, O. A. (2010). Vykorystannia metodu kontentanalizu dlia doslidzhennia katehorialno-poniattievoho aparatu u systemi pedahohichnoho znannia. (Use of content analysis method for research of categoricalconceptual apparatus in the system of pedagogical knowledge.) Vinnytsia : Vyd-vo AMSKP, 200221.

Zhyhir, V. I., Chernieha, O. A. (2012). Profesiina pedahohika (Professional pedagogy). Kyiv : Kondor.

Zabiiako, Yu. (2013). Profesiina pidhotovka fakhivtsiv fizychnoi kultury ta sportu. (Professional training of specialists in physical culture and sports). Fizychne vykhovannia, sport i kultura zdorovia u suchasnomu suspilstvi, 2 .

Ivasiv, N. S. (2017). Profesiina inshomovna pidhotovka maibutnikh fakhivtsiv z turyzmoznavstva yak pedahohichna problema. (Professional foreign language training of future specialists in tourism as a pedagogical problem). Science and Education a New Dimension, 54 (126), 21-25.

Kremen, V. H. (1999). Natsionalna osvita yak sotsiokulturne yavyshche. (National education as a sociocultural phenomenon). Uchytel, 1112. 10-17.

Liannoi, Yu. O. (2017). Teoretychni i metodychni zasady profesiinoi pidhotovky maibutnikh mahistriv z fizychnoi reabilitatsii u vyshchykh navchalnykh zakladakh. (Theoretical and methodological principles of professional training of future masters in physical rehabilitation in higher educational establishmentsdysertatsiia doktora pedahohichnykh nauk. Natsionalnyi pedahohichnyi universytet imeni M. P. Drahomanova. Kyiv.

Pavlyk, O. B. (2004). Profesi ino-pedahohichna pidhotovka maibutnikh perekladachiv do vykorystannia ofitsiino-dilovoho movlennia ( Profes sion a 1-pedagogical preparation of future translators for use of official business language). (Avtoref. dys. ... kand. ped. nauk). Khmelnytskyi.

Slovnyk psykholohopedahohichnykh poniat. (2012). (Dictionary of psychological and pedagogical concepts).

Tlumachnyi slovnyk ukrainskoi movy. (2012). (Ukrainian language dictionary). Retrieved from http:// sum.in.ua/f.

Trotsko, H. V. (1997). Teoretychni ta metodychni osnovy pidhotovky studentiv do vykhovnoi diialnosti u vyshchykh pedahohichnykh navchalnykh zakladakh. (Theoretical and methodological bases of preparation of students for educational activity in higher pedagogical institutions). (Avtoref. dys. ... doktora ped. Nauk). Instytut PPPO. Kyiv.

Tsiuniak, O. (2019). Filosofsjke osmyslennja ponjattja "innovacijna dijaljnistj". Philosophical understanding of the concept of "innovative activity". Molodyj vchenyj, 5, 175-178.

Стаття надійшла 22.03.2020 p. 